\title{
The effect of 3 or 6 weeks feeding of diets containing different fat source and content on deoxycorticosterone $11 \beta$-hydroxylase activity in adrenal gland and on plasma corticosterone and leptin concentration in rats
}

\author{
M. Stachoń, J. Gromadzka-Ostrowska, M. Przepiórka \\ and E. Fürstenberg
}

\author{
Department of Dietetics and Functional Foods, \\ Faculty of Human Nutrition and Consumer Sciences, Warsaw Agricultural University \\ Nowoursynowska 159c, 02-778 Warsaw, Poland
}

(Received 9 December 2002; revised version 26 May 2003; accepted 15 July 2003)

\begin{abstract}
Our study aimed at investigating the impact of different levels (increased $-10 \%$ and high $-20 \%$; $\mathrm{w} / \mathrm{w}$ ) and types (sunflower oil, rapeseed oil, cod liver oil, lard) of fat in the diet on the activity of the key enzyme in the corticosterone (Cs) biosynthesis pathway in adrenal cortex i.e. deoxycorticosterone $11 \beta$-hydroxylase (11 $\beta$-OHase) (it was expressed as a percent of conversion of $\left[{ }^{14} \mathrm{C}\right]$ deoxycorticosterone into $\left[{ }^{14} \mathrm{C}\right]$ corticosterone during $2 \mathrm{~h}$ incubation) and on plasma corticosterone and leptin concentration (measured by RIA method) in rats. 102 male Wistar rats were fed their experimental diets for 3 or 6 weeks. All parameters were found to be significantly affected by dietary fat source. Rats fed the diet containing cod liver oil had the highest $11 \beta$-OHase activity, while those fed sunflower oil diet had the lowest. Sunflower and rapeseed oil diets brought about higher plasma leptin concentration than cod liver oil and lard diets. Plasma Cs concentration in rats fed cod liver oil diet was higher than in rats fed other fat diets. Additionally, diets containing $20 \%$ of fat caused higher enzyme activity than diets containing $10 \%$ of fat. There was no effect of fat level in diet on plasma Cs and leptin concentration. These effects were observed in rats fed for six weeks only for enzyme activity and in rats fed for three weeks for plasma Cs concentration. Moreover, $11 \beta$-OHase activity increased after 6 weeks of experiment, plasma Cs level - decreased after the same time.
\end{abstract}

KEY WORDS: adrenal cortex, corticosterone, $11 \beta$-hydroxylase, leptin, dietary fat, rats 


\section{INTRODUCTION}

Leptin and glucocorticoids are two of the most important peripherally synthesized and secreted hormones that play a crucial role in the regulation of energy balance of an organism. The studies that have been performed up to now show that leptin and glucocorticoids act antagonistically in the regulation of food intake, body mass and energy expenditure (Strack et al., 1995; Korbonits et al., 1997; Zakrzewska et al., 1997; Arvaniti et al., 1998).

A matter under discussion is the hormonal feedback loop between adipose tissue and HPA (hypothalamic-pituitary-adrenal) axis (De Vos et al., 1995; Wabitsch et al., 1996; Blum, 1997; Solano et al., 1999). Adrenal hormones in both physiological and pathologically high concentrations stimulate expression of ob gene in the adipose tissue, while leptin has an inhibitory effect on HPA axis acting both centrally through NPY and peripherally by inhibition of steroidogenesis in the cells of adrenals (Heiman et al., 1997; Pralong et al., 1998).

Glucocorticoids and leptin play an important role in the pathogenesis of both diet independent and diet dependent obesity (Trocki et al., 1995; Tataranni et al., 1996). Fat is one of the main dietary components, thus amount of fat consumed and its composition significantly affects the development of obesity. High fat level in the diet is connected with an increase in the concentration of free fatty acids in the blood, which in turn stimulates the activity of HPA axis (Tannenbaum et al., 1997; Kamara et al., 1998). Consumption of high fat diets results also in the increase in ob gene expression in the adipose tissue and higher blood leptin concentration which probably protect the organism against the development of diet dependent obesity (Lin et al., 1998, 2000; Stricker-Krongrad et al., 1998). On the other hand, fat composition (content of particular fatty acids) influences the composition and functions of cell membranes, as well as intracellular metabolism (Vallette et al., 1991; Innis et al., 1995; Widmaier, 1997; Raatz et al., 2001). These mechanisms seem to play an important role in the regulation of synthesis, secretion and cellular activity of leptin and adrenal hormones (Widmaier, 1997; Heshka et al., 2001).

In this respect, the aim of the present study was to examine the influence, if any, of diets with different fat level and composition on some aspects of hormonal regulation of energy balance (blood leptin and Cs concentration), as well as on the activity of the key enzyme in the corticosterone biosynthesis pathway in adrenal cortex i.e. deoxycorticosterone $11 \beta$-hydroxylase.

\section{MATERIAL AND METHODS}

\section{Animals}

The experiment was performed on 102 male Wistar rats (initial body weight 240-260 g). Animals were housed in individual stainless cages in a temperature 
$\left(22^{\circ} \mathrm{C}\right)$ and humidity $(50 \%)$ controlled room with $12 \mathrm{~h} / 12 \mathrm{~h}$ light-dark cycle. All animals had free access to food and water throughout the experiment.

Diets

Following two-week adaptation period the animals were at random divided into eight groups fed different diets. Diets differed with respect to fat level (10 and $20 \% \mathrm{w} / \mathrm{w}$ ) and fat type (sunflower oil, rapeseed oil, cod liver oil and lard). The composition of diets is shown in Table 1. Content of particular fatty acids in the experimental fats was analysed by gas chromatography and data on fats composition are summarized in Table 2. Animals were fed experimental diets for three or six weeks. Diet intake was recorded daily and body weight gain was recorded every three days. At the end of the experimental period, rats were etherized, both adrenals were dissected and heart blood was collected into heparinized tubes. Blood was centrifuged to obtain plasma and aliquots were frozen at $-23^{\circ} \mathrm{C}$. Adrenals were rinsed, blotted and snap frozen in liquid nitrogen and stored at $-80^{\circ} \mathrm{C}$ until biochemical analyses. Dissections were performed in the period of two same hours of light phase each day.

TABLE 1

The composition of experimental diets: LF diet - low fat diet, HF diet - high fat diet

\begin{tabular}{lcc}
\hline \multirow{2}{*}{ Components } & \multicolumn{2}{c}{ Content, g/100 g of the diet } \\
\cline { 2 - 3 } & LF diet & HF diet \\
\hline Wheat starch & 59 & 49 \\
Casein & 22 & 22 \\
Fat & 10 & 20 \\
Potato starch & 5 & 5 \\
Vitamin mixture & 3 & 3 \\
Mineral mixture & 1 & 1 \\
Choline & 0.2 & 0.2 \\
Energy value., kcal/g & 4.14 & 4.64 \\
& & \\
Energy supplied by, $\%$ & & 42.2 \\
$\quad$ carbohydrates & 57.0 & 38.8 \\
$\quad$ fat & 21.7 & 19.0 \\
$\quad$ protein & 21.3 &
\end{tabular}

${ }^{a}$ composition of the vitamin mixture (per $100 \mathrm{~g}$ of mixture): vit. A, $200000 \mathrm{IU}$; vit. D, $20000 \mathrm{IU}$; vit. E, $1000 \mathrm{IU}$; vit. K, $50 \mathrm{mg}$; PABA, $1 \mathrm{~g}$; inosytol, $1 \mathrm{~g}$; niacin, $400 \mathrm{mg}$; calcium pantothenate, 400 $\mathrm{mg}$; ryboflavin, $80 \mathrm{mg}$; thiamin chloride, $50 \mathrm{mg}$; pyridoxine chloride, $50 \mathrm{mg}$; folic acid, $20 \mathrm{mg}$; biotin, $4 \mathrm{mg}$; vit. $\mathrm{B}_{12}, 0,3 \mathrm{mg}$

${ }^{\mathrm{b}}$ composition of the mineral mixture (per $100 \mathrm{~g}$ of mixture): $\mathrm{CaHPO}_{4}, 73.5 \mathrm{~g} ; \mathrm{K}_{2} \mathrm{HPO}_{4}, 8.1 \mathrm{~g} ; \mathrm{K}_{2} \mathrm{SO}_{4}, 6.8$ g; NaCl, 3.06 g; $\mathrm{CaCO}_{3}, 2.1 \mathrm{~g} ; \mathrm{NaHPO}_{4}, 2.14 \mathrm{~g} ; \mathrm{MgO}, 2.5$ g; $\mathrm{C}_{3} \mathrm{H}_{4}(\mathrm{OH})(\mathrm{COO})_{2} \mathrm{Fe}, 558 \mathrm{mg} ; \mathrm{ZnCO}_{3}, 81$ $\mathrm{mg}, \mathrm{MnCO}_{3}, 421 \mathrm{mg} ; \mathrm{CuCO}_{3}, 33 \mathrm{mg} ; \mathrm{KJ}, 720 \mu \mathrm{g} ; \mathrm{C}_{3} \mathrm{H}_{4}(\mathrm{OH})(\mathrm{COOH})_{3}, 706 \mathrm{mg}$ 
TABLE 2

Content [\%] of particular fatty acids and total saturated fatty acids (SFAs), monounsaturated fatty acids (MUFAs) and polyunsaturated fatty acids (PUFAs) content in the experimental diets

\begin{tabular}{lcccc}
\hline \multirow{2}{*}{ Fatty acids } & \multicolumn{4}{c}{ Experimental fats } \\
\cline { 2 - 5 } & sunflower oil $^{\mathrm{a}}$ & rapeseed oil & cod liver oil $^{\mathrm{b}}$ & lard $^{\mathrm{d}}$ \\
\hline C 16:0 & 6.0 & 5.44 & 16.78 & 34.58 \\
C 18:0 & 3.4 & 1.19 & 2.35 & 19.1 \\
E SFAs & 10.5 & 6.63 & 23.07 & 54.69 \\
C 18:1 & 22.18 & 62.31 & 27.55 & 40.98 \\
$\sum$ MUFAs & 23.02 & 62.85 & 55.07 & 42.16 \\
C 18:2 & & & 0.06 & 3.13 \\
C 20:5 & 65.91 & 25.16 & 9.13 & \\
C 22:6 & & & 11.88 & 3.13 \\
$\sum$ PUFAs & 66.31 & 30.52 & 21.83 & \\
\hline
\end{tabular}

${ }^{\mathrm{a}, \mathrm{b}}$ sunflower and rapeseed oils from Warsaw Oil Plant

c cod liver oil from „LYSI” / ICELAND

d lard from Warsaw Meat Plant „Służewiec”

\section{Analytical methods}

Deoxycorticosterone 11 -hydroxylase activity. The enzyme activity was measured by the method described by Lo et al. (1998) with modifications we ourselves introduced. Adrenals were homogenized in TRIS- $\mathrm{HCl}$ buffer $\left(0,01 \mathrm{M}\right.$; $\mathrm{pH} 7,5$ at $\left.37^{\circ} \mathrm{C}\right)$. For measurements complete adrenals homogenates were used. The method consists in converting $\left[{ }^{14} \mathrm{C}\right]$ deoxycorticosterone $\left(\left[{ }^{14} \mathrm{C}\right] \mathrm{DOC}\right)$ into $\left[{ }^{14} \mathrm{C}\right]$ corticosterone $\left(\left[{ }^{14} \mathrm{C}\right] \mathrm{Cs}\right)$ during two-hours incubation at $37^{\circ} \mathrm{C}$. Reaction of conversion was stopped by watersaturated ethyl acetate. Ethyl acetate was also used for triple extraction of both radioactive compounds. Mixed extracts were vaporized in the nitrogen atmosphere, then quantitatively spotted on chromatographic plates (TLC aluminium sheets 20 x $20 \mathrm{~cm}$; silica gel $60 \mathrm{~F}_{254 ;}$ Merck) and chromatographed in chloroform/acetone $(4: 1, \mathrm{vol} / \mathrm{vol})$ solution. Spots containing $\left[{ }^{14} \mathrm{C}\right] \mathrm{DOC}$ and $\left[{ }^{14} \mathrm{C}\right] \mathrm{Cs}$ were located under ultraviolet light and cut off and subsequently beta counter measured their radioactivity. The enzyme activity was expressed as percentage of conversion of $\left[{ }^{14} \mathrm{C}\right] \mathrm{DOC}$ into $\left[{ }^{14} \mathrm{C}\right] \mathrm{Cs}$ of $\mathrm{x} 100 \%$ per mg adrenal homogenate protein as determined by the method of Lowry's et al. (1951).

Plasma corticosterone concentration. Plasma corticosterone was measured by radioimmunoassay method using ${ }^{125}$ I RIA KIT (ICN Biomedicals, Inc; USA). Results were expressed as $\mathrm{ng} / \mathrm{ml}$ plasma.

Plasma leptin concentration. Plasma leptin was determined by radioimmunoassay method using RAT LEPTIN RIA KIT (Linco Research, Inc; USA). Results were expressed as $\mathrm{ng} / \mathrm{ml}$ plasma. 


\section{Statistical analyses}

To determine the influence of fat type and fat level in the diet as well as feeding period on parameters studied, results were statistically evaluated using multifactor analysis of variance (ANOVA) and where appropriate (i.e. after a significant main effect), followed by post hoc Fisher's least significant difference (LSD) test for the specific comparisons between particular group means. Finally, correlations between parameters were also evaluated. The level of significance was set at $\mathrm{P} \leq 0.05$. Statistical analyses were carried out by means of STATGRAPHICS Plus 4.1 (Statistical Graphic, Bitstream, Cambridge, MA) software.

\section{RESULTS}

\section{Final body weight and body weight gain}

Final body weight and daily body weight gain were found to be significantly higher in rats fed $20 \%$ fat diets $(\mathrm{P}<0.002)$ and sunflower oil $(\mathrm{P}<0.02)$ than in animals fed diets containing $10 \%$ fat or other fat types. Obviously, animals receiving the experimental diets for six weeks attained higher final body weights and gained more body weight per day ( $\mathrm{P}<0.0001$ for both parameters), as compared to animals fed for only three weeks. Nevertheless, the daily gain in body weight was higher in rats fed the diets for shorter period of time (three weeks) than in those fed for a longer period of time (i.e. six weeks) $(\mathrm{P}<0.04)$. Data on these two parameters are shown in Table 3.

\section{Intake of food, energy, fat and fatty acids}

Rats consumed more diet containing less fat per day than diet richer in this component $(\mathrm{P}<0.0001)$; daily food intake during 3-weeks experiment was greater than during 6-weeks experiment $(\mathrm{P}<0.0001)$.

Daily intakes of energy, fat and fatty acids were higher in rats receiving $20 \%$ fat diet as compared to animals fed $10 \%$ fat diets $(\mathrm{P}<0.0001$ for all parameters $)$ and in animals fed the diets for 3 weeks than in rats fed for 6 weeks $(\mathrm{P}<0.0001$ for all parameters). With respect to fat type, intake of sunflower oil diets by rats was significantly higher as compared to diets containing other fats. The lowest diet intake was found for the cod liver oil $(\mathrm{P}<0.001)$.

Intake of particular groups of fatty acids (saturated fatty acids - SFAs, monounsaturated fatty acids - MUFAs, and polyunsaturated fatty acids - PUFAs) was related to the composition of experimental fats (Table 4). As lard and to a lesser extent cod liver oil are rich in SFAs, diets containing these fats were the sources 
TABLE 3

Final body weight and daily body weight gain (mean $\pm \mathrm{SD} ; \mathrm{n}=6$ for each group). Animals received $10 \%$ (10) or $20 \%$ (20) of: sunflower oil (S), rapeseed oil (R), cod liver oil (C) or lard (L) in the diet

\begin{tabular}{lccc}
\hline $\begin{array}{l}\text { Duration of } \\
\text { experiment }\end{array}$ & Group & $\begin{array}{c}\text { Final body weight } \\
\text { g }\end{array}$ & $\begin{array}{c}\text { Body weight gain } \\
\text { g/day }\end{array}$ \\
\hline 3 weeks & $10 \mathrm{~S}$ & $353.7 \pm 15.8$ & $3.72 \pm 0.65$ \\
& $10 \mathrm{R}$ & $351.0 \pm 6.1$ & $3.44 \pm 0.39$ \\
$10 \mathrm{C}$ & $355.2 \pm 15.1$ & $3.40 \pm 0.25$ \\
$10 \mathrm{~L}$ & $371.2 \pm 24.8$ & $3.70 \pm 0.66$ \\
& $20 \mathrm{~S}$ & $379.0 \pm 27.6$ & $4.98 \pm 1.10^{\mathrm{a}}$ \\
& $20 \mathrm{R}$ & $372.2 \pm 7.9$ & $3.89 \pm 0.29^{\mathrm{b}}$ \\
& $20 \mathrm{C}$ & $374.0 \pm 14.9$ & $3.52 \pm 0.60^{\mathrm{b}}$ \\
& $20 \mathrm{~L}$ & $371.3 \pm 23.9$ & $4.49 \pm 0.65$ \\
& & & \\
& $10 \mathrm{~S}$ & $419.3 \pm 33.9^{\mathrm{a}}$ & $3.92 \pm 0.89^{\mathrm{a}}$ \\
& $10 \mathrm{R}$ & $389.0 \pm 30.9^{\mathrm{b}}$ & $3.31 \pm 0.74$ \\
& $10 \mathrm{C}$ & $390.8 \pm 21.1^{\mathrm{b}}$ & $3.45 \pm 0.41$ \\
& $10 \mathrm{~L}$ & $370.2 \pm 21.5^{\mathrm{b}}$ & $2.99 \pm 0.46^{\mathrm{b}}$ \\
& $20 \mathrm{~S}$ & $424.3 \pm 16.6^{\mathrm{a}}$ & $4.19 \pm 0.52$ \\
& $20 \mathrm{R}$ & $401.5 \pm 18.1$ & $3.75 \pm 0.59$ \\
& $20 \mathrm{C}$ & $398.0 \pm 17.9^{\mathrm{b}}$ & $3.45 \pm 0.58$ \\
& $20 \mathrm{~L}$ & $386.3 \pm 24.1^{\mathrm{b}}$ & $3.74 \pm 0.92$ \\
\hline
\end{tabular}

a,b different letters indicate significant $(\mathrm{P}<0.05)$ differences between groups of rats fed diets containing different source of fat but the same fat level. The influence of fat content in diets and feeding period are described in text

of the highest amounts of saturated fatty acids $(\mathrm{P}<0.0001)$. Rapeseed oil and cod liver oil contain considerable amounts of MUFAs, thus the animals fed these diets consumed mainly monounsaturated fatty acids. Since sunflower oil is the richest source of PUFAs among fats used in this study, consumption of polyunsaturated fatty acids was the highest in animals fed diets containing this type of fat $(\mathrm{P}<0.0001)$. Data on intake are shown in Table 4.

\section{Activity of deoxycorticosterone $11 \beta$-hydroxylase}

Preliminary statistical analysis revealed the significant influence of the level and type of fat in the diet on the enzyme activity. Rats receiving $20 \%$ fat diets showed higher activity of the enzyme than $10 \%$ fat groups $(\mathrm{P}<0.0001) .11 \beta$-OHase activity reached its zenith in animals fed cod liver oil diets and the lowest enzyme activity was found for sunflower oil groups $(\mathrm{P}<0.0001)$ (Figures 1A and $\mathrm{B})$. 
TABLE 4

Intake of food, energy, fat, saturated fatty acids (SFAs), monounsaturated fatty acids (MUFAs) and polyunsaturated fatty acids (PUFAs) (mean $\pm \mathrm{SD} ; \mathrm{n}=6$ for each group). Animals received $10 \%$ (10) or $20 \%$ (20) of: sunflower oil (S), rapeseed oil (R), cod liver oil (C) or lard (L) in the diet for three (3) or six (6) weeks

\begin{tabular}{ccccccc}
\hline Groups & $\begin{array}{c}\text { Food intake } \\
\text { g/day }\end{array}$ & $\begin{array}{c}\text { Energy intake } \\
\text { kJ/day }\end{array}$ & $\begin{array}{c}\text { Fat intake } \\
\text { g/day }\end{array}$ & $\begin{array}{c}\text { SFAs intake } \\
\text { g/day }\end{array}$ & $\begin{array}{c}\text { MUFAs intake PUFAs intake } \\
\text { g/day }\end{array}$ & g/day \\
\hline $10 \mathrm{~S}-3$ & $6.47 \pm 0.15^{\mathrm{a}}$ & $110.1 \pm 2.47^{\mathrm{a}}$ & $0.65 \pm 0.02^{\mathrm{a}}$ & $0.07 \pm 0.002^{\mathrm{a}}$ & $0.15 \pm 0.004^{\mathrm{a}}$ & $0.43 \pm 0.01^{\mathrm{a}}$ \\
$10 \mathrm{R}-3$ & $5.95 \pm 0.5^{\mathrm{b} . \mathrm{c}}$ & $101.2 \pm 7.64^{\mathrm{b}}$ & $0.59 \pm 0.05$ & $0.04 \pm 0.003^{\mathrm{b}}$ & $0.37 \pm 0.03^{\mathrm{b}}$ & $0.18 \pm 0.01^{\mathrm{b}}$ \\
$10 \mathrm{C}-3$ & $5.65 \pm 0.35^{\mathrm{b}}$ & $96.1 \pm 6.00^{\mathrm{b}}$ & $0.56 \pm 0.04^{\mathrm{b}}$ & $0.13 \pm 0.008^{\mathrm{c}}$ & $0.27 \pm 0.11^{\mathrm{c}}$ & $0.12 \pm 0.01^{\mathrm{c}}$ \\
$10 \mathrm{~L}-3$ & $6.11 \pm 0.36^{\mathrm{c}}$ & $103.9 \pm 6.14$ & $0.61 \pm 0.04$ & $0.33 \pm 0.02^{\mathrm{d}}$ & $0.26 \pm 0.01^{\mathrm{d}}$ & $0.02 \pm 0.001^{\mathrm{d}}$ \\
$20 \mathrm{~S}-3$ & $5.78 \pm 0.52$ & $110.5 \pm 9.87$ & $1.16 \pm 0.10$ & $0.12 \pm 0.01^{\mathrm{a}}$ & $0.27 \pm 0.02^{\mathrm{a}}$ & $0.77 \pm 0.07^{\mathrm{a}}$ \\
$20 \mathrm{R}-3$ & $5.77 \pm 0.40$ & $110.2 \pm 7.63$ & $1.15 \pm 0.08$ & $0.08 \pm 0.005^{\mathrm{b}}$ & $0.72 \pm 0.05^{\mathrm{b}}$ & $0.35 \pm 0.02^{\mathrm{b}}$ \\
$20 \mathrm{C}-3$ & $5.56 \pm 0.47$ & $106.3 \pm 8.91$ & $1.11 \pm 0.10$ & $0.26 \pm 0.02^{\mathrm{c}}$ & $0.61 \pm 0.05^{\mathrm{c}}$ & $0.24 \pm 0.02^{\mathrm{c}}$ \\
$20 \mathrm{~L}-3$ & $5.56 \pm 0.16$ & $106.1 \pm 3.05$ & $1.11 \pm 0.03$ & $0.61 \pm 0.02^{\mathrm{d}}$ & $0.47 \pm 0.01^{\mathrm{d}}$ & $0.03 \pm 0.001^{\mathrm{d}}$ \\
$10 \mathrm{~S}-6$ & $4.99 \pm 0.23$ & $84.9 \pm 3.98$ & $0.50 \pm 0.02$ & $0.05 \pm 0.003^{\mathrm{a}}$ & $0.11 \pm 0.005^{\mathrm{a}}$ & $0.33 \pm 0.01^{\mathrm{a}}$ \\
$10 \mathrm{R}-6$ & $4.91 \pm 0.26$ & $83.5 \pm 4.46$ & $0.49 \pm 0.03$ & $0.03 \pm 0.001^{\mathrm{b}}$ & $0.31 \pm 0.02^{\mathrm{b}}$ & $0.15 \pm 0.01^{\mathrm{b}}$ \\
$10 \mathrm{C}-6$ & $4.79 \pm 0.11$ & $81.4 \pm 1.83$ & $0.48 \pm 0.01$ & $0.11 \pm 0.002^{\mathrm{c}}$ & $0.26 \pm 0.01^{\mathrm{c}}$ & $0.1 \pm 0.002^{\mathrm{c}}$ \\
$10 \mathrm{~L}-6$ & $4.93 \pm 0.07$ & $83.9 \pm 1.24$ & $0.49 \pm 0.01$ & $0.27 \pm 0.004^{\mathrm{d}}$ & $0.18 \pm 0.07^{\mathrm{d}}$ & $0.01 \pm 0.001^{\mathrm{d}}$ \\
$20 \mathrm{~S}-6$ & $4.69 \pm 0.37$ & $89.5 \pm 7.01$ & $0.94 \pm 0.07$ & $0.1 \pm 0.008^{\mathrm{a}}$ & $0.22 \pm 0.02^{\mathrm{a}}$ & $0.62 \pm 0.05^{\mathrm{a}}$ \\
$20 \mathrm{R}-6$ & $4.81 \pm 0.23^{\mathrm{a}}$ & $91.9 \pm 4.27^{\mathrm{a}}$ & $0.96 \pm 0.04^{\mathrm{a}}$ & $0.06 \pm 0.003^{\mathrm{b}}$ & $0.6 \pm 0.03^{\mathrm{b}}$ & $0.29 \pm 0.01^{\mathrm{b}}$ \\
$20 \mathrm{C}-6$ & $4.42 \pm 0.23$ & $84.3 \pm 4.36^{\mathrm{b}}$ & $0.88 \pm 0.05^{\mathrm{b}}$ & $0.2 \pm 0.01^{\mathrm{c}}$ & $0.49 \pm 0.02^{\mathrm{c}}$ & $0.19 \pm 0.01^{\mathrm{c}}$ \\
$20 \mathrm{~L}-6$ & $4.57 \pm 0.16^{\mathrm{b}}$ & $87.3 \pm 3.13$ & $0.91 \pm 0.03$ & $0.5 \pm 0.02^{\mathrm{d}}$ & $0.39 \pm 0.01^{\mathrm{d}}$ & $0.03 \pm 0.001^{\mathrm{d}}$ \\
\hline
\end{tabular}

a,b,c,d different letters indicate significant differences $(\mathrm{P}<0.05)$ between groups of rats fed diets containing different source of fat but the same fat level. The influence of fat content in diets and feeding period are described in text

However, comparison between group means by Fisher test showed that these observations held true only for six-week groups, while three-week groups did not differ with respect to the enzyme activity. Furthermore it is worth stressing that deoxycorticosterone $11 \beta$-hydroxylase activity in adrenals of rats offered experimental diets for six weeks was significantly higher than in animals receiving diets for three weeks $(\mathrm{P}<0.0001)$.

\section{Plasma corticosterone concentration}

Statistical analysis of results showed the significant influence of dietary fat type on plasma corticosterone concentration. Blood plasma of rats consuming cod liver diets was found to have higher concentration of corticosterone as compared to rats offered diets containing other fat types $(\mathrm{P}<0.05)$. However, as shown by post hoc analysis by Fisher test, this holds true for groups fed experimental diets for three weeks only. There were no significant differences between six-week groups 

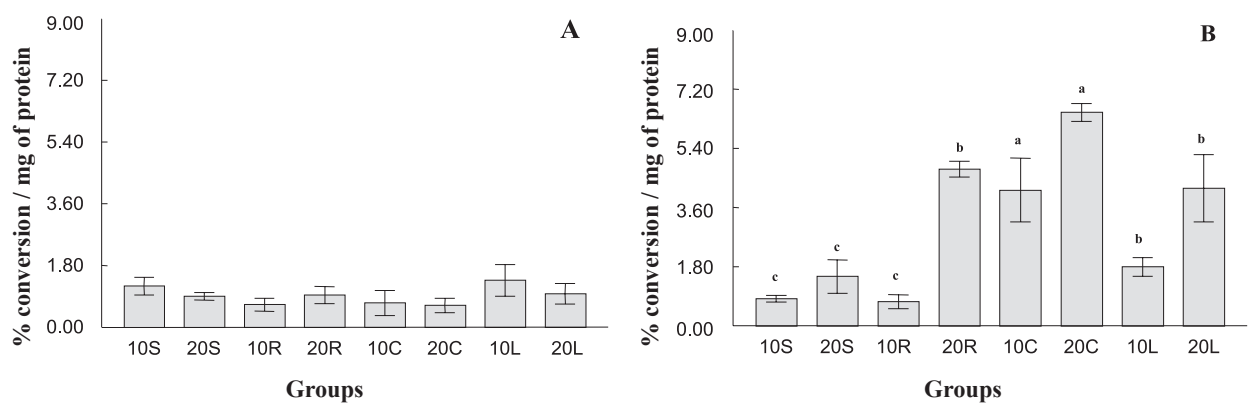

Figure 1. Activity of $11 \beta$-deoxycorticosterone hydroxylase in adrenals homogenates of rats fed experimental diets for three (A) or six (B) weeks (mean $\pm \mathrm{SD} ; \mathrm{n}=6$ for each group). X-axis description: 10 and 20 - fat content in the diet (10\% and 20\%, respectively), S - sunflower oil, R - rapeseed oil, C - cod liver oil, L - lard. On figure B different letters $(a, b)$ indicate significant differences $(P<0.05)$ between groups of rats fed different source of fat but the same fat level. There was significant influence of fat content in diet on enzyme activity in all of these groups. There were no differences between groups on figure A
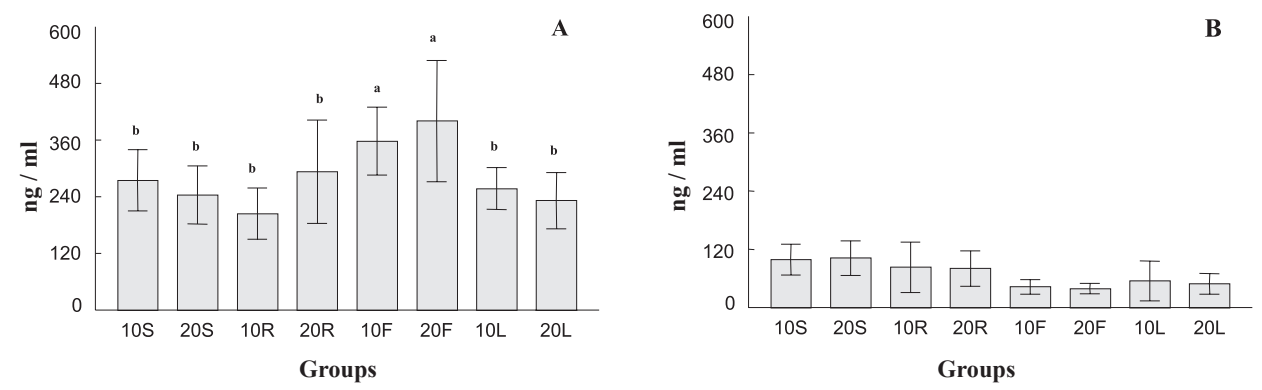

Figure 2. Plasma corticosterone concentration in rats fed experimental diets for three (A) or six (B) weeks (mean $\pm \mathrm{SD} ; \mathrm{n}=6$ for each group). $\mathrm{X}$-axis description as in Figure 1. On figure A different letters $(\mathrm{a}, \mathrm{b})$ indicate significant differences $(\mathrm{P}<0.05)$ between groups of rats fed different source of fat. There was no effect of fat content in diet. There were no differences between groups on figure B

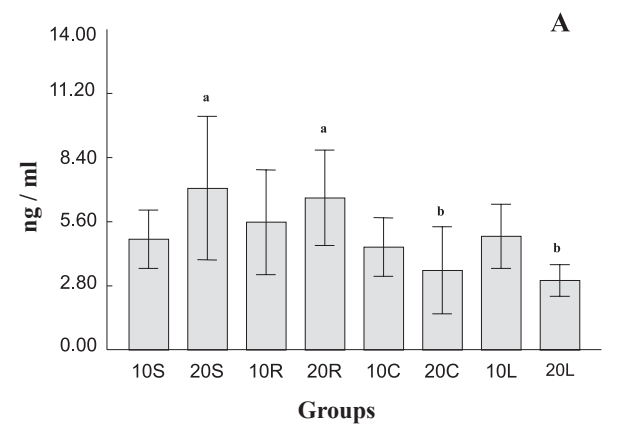

A

B

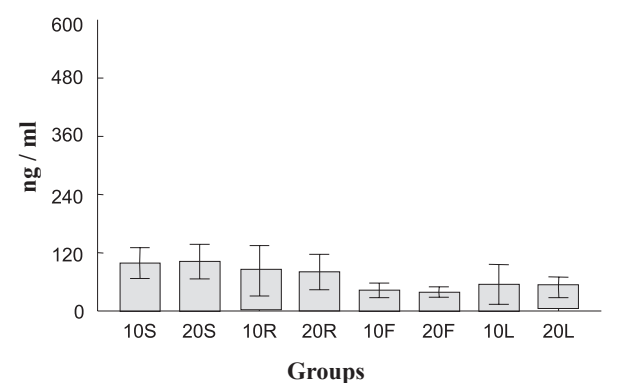

Figure 3. Plasma leptin concentration in rats fed for three (A) or six (B) weeks (mean $\pm S D$; $n=6$ for each group). $\mathrm{X}$-axis description as in Figure 1. Different letters $(\mathrm{a}, \mathrm{b})$ indicate significant differences $(\mathrm{P}<0.05)$ between groups of rats fed diets containing different source of fat but the same fat level. There was no effect of fat content in diet 
(Figures 2A and B). With respect to duration of experiment, plasma corticosterone concentration was lower in rats fed for six weeks than in animals fed for shorter period of time (three weeks) $(\mathrm{P}<0.0001)$. Fat level in the diets did not affect the plasma concentration of corticosterone.

\section{Plasma leptin concentration}

In the present study, fat type in the diet was a substantial factor that influenced significantly plasma leptin concentration. Plasma leptin concentration was considerably higher in rats offered sunflower oil and rapeseed oil diets as compared to cod liver oil and lard groups $(\mathrm{P}<0.001)$ (Figures $3 \mathrm{~A}$ and $\mathrm{B})$. Both fat level and duration of experiment did not have any impact on plasma leptin concentration.

\section{DISCUSSION}

In the present study we hypothesized that adrenal synthesis of corticosterone (deoxycorticosterone 11 $\beta$-hydroxylase catalyses the last step in the biosynthesis pathway of corticosterone i.e. oxidation of deoxycorticosterone to corticosterone, thus $11 \beta$-OHase may be regarded as one of the key enzymes in this process) and secretion of this hormone into blood may be modified not only by fat level but also by fat type in the diet. We also assumed that both factors might significantly influence plasma leptin concentration.

Experimental diets contained 10 and $20 \%(\mathrm{w} / \mathrm{w})$ fat, both levels being higher than in standard diets for rats. $20 \%$ diets can be even regarded as high fat diets. The selection of experimental fat ensued from the fat composition, predominantly from the content of particular fatty acids. Sunflower oil and rapeseed oil are vegetable fats rich in unsaturated fatty acids. Sunflower oil contains more polyunsaturated fatty acids, while rapeseed oil is richer in monounsaturated fatty acids. Animal fats - cod liver oil and lard are rich in saturated fatty acids and monounsaturated fatty acids. Furthermore, cod liver oil contains a fair amount of polyunsaturated fatty acids, mainly docosahexaenoic acid (C 22:6), which is not found in other fats.

Rats were fed their experimental diets for 3 and 6 weeks. The three-week feeding period allowed us to study short-term adaptive changes in investigated parameters to diets, while six-week experiment was found to be long enough to uncover long-term adaptive processes. Widmaier et al. (1992) assumed that blood's free fatty acids (FFAs) could be a part of negative feedback in HPA axis and could inhibit adrenal secretion of glucocorticoids. In states such as hypoglycaemia, GCs stimulate lipolysis in adipose tissue and thus contribute to the increase in free fatty acids concentration in the blood. This lipolytic attribute of GCs justifies the aforementioned assumption. In vivo in rats, however, the authors showed a 
stimulatory effect of increased free fatty acids concentration in the blood on the secretion of ACTH in the pituitary and on adrenal secretion of corticosterone. Further research by Sarel et al. (1995) conducted in cultures of fascicular zone cells of bovine adrenals has broadened these results. Pathologically high concentration of long-chain fatty acids (oleic acid and linoleic acid) was shown to stimulate the process of steroidogenesis. This stimulation reached the level of half the production of ACTH-stimulated corticosterone production. Saturated fatty acids appeared to be completely ineffective in this respect.

Fatty acids show a broad scope of impact on cellular functions and different mechanisms are considered as to the stimulation of adrenal steroidogenesis by long-chain fatty acids (Widmaier, 1997).

As already mentioned, increase in blood FFAs concentration may result not only from stressful stimuli of hypoglycaemia, fasting or non-controlled diabetes, but also from consumption of high fat diet (Widmaier, 1997; Kamara et al., 1998). Moreover, the composition of dietary fat determines the concentration of particular fatty acids in the blood, as well as in plasma and cell membrane phospholipids (Innis et al., 1995; Raatz et al., 2001).

Consumption of high fat diets is associated with incidence of many metabolic disorders such as lipid and glucose metabolism disorders, hyperinsulinaemia and insulin resistance. These are the main risk factors for the development of many civilization-related diseases such as hypertension, non-insulin-dependent diabetes mellitus, obesity and atherosclerosis (Wang et al., 1998). Long-term hypersecretion of glucocorticoids may bring about similar effects (Tataranni et al., 1996; Leakey et al., 1998). Additionally, high fat intake may be a factor stimulating the activity of HPA axis. These facts were the basis for the study performed by Tannenbaum et al. (1997). Researchers demonstrated that high-fat feeding augments both the $\mathrm{ACTH}$ and corticosterone responses to acute stress in rats, as well as increases in basal corticosterone secretion. Furthermore, they have shown that high-fat feeding results in insulin resistance and elevations in both basal and stress - induced free acids and blood glucose concentration. The authors suggest that dietary fat intake acts as a background form of chronic stress, elevating basal corticosterone levels and enhancing HPA axis responses to stress.

Results of our study did not demonstrate any stimulating effect of high fat diets $(20 \% \mathrm{w} / \mathrm{w})$ on plasma corticosterone concentration as compared to the diets containing twice less fat $(10 \% \mathrm{w} / \mathrm{w})$. However, such an effect was observed at the level of adrenal steroidogenesis, i.e. for 11ß-OHase activity. Interestingly, this effect was observed only after six-week period of experiment, while the three-week groups did not differ with respect to this parameter.

Furthermore, significant differences were found between groups offered experimental diets for 6 weeks, as regards the influence of fat type in the diet on the enzyme activity. Thus, the differentiation or likely adaptation in adrenal 
steroidogenesis to diets occurred only after six weeks. As the highest activity of $11 \beta-$ OHase was found in animals fed diets containing cod liver oil as a source of fat, this type of dietary fat evidently stimulated the oxidation reaction of deoxycorticosterone to corticosterone. Cod liver oil is a fat rich in monounsaturated fatty acids (mainly oleic acid C 18:1) and in polyunsaturated fatty acids, among which docosahexaenoic acid (C 22:6) is most abundant. The studies by Widmaier et al. (1992) and Sarel et al. (1995) indicated that increased level of both oleic and linoleic acids brought about in vitro stimulation of steroidogenesis in rat adrenal cortex cells and increase in secretion of corticosterone and ACTH into blood in vivo. In the present study we found the significant positive correlation between MUFAs intake and adrenal $11 \beta$-OHase activity $(\mathrm{r}=0.23 ; \mathrm{P}<0.03)$. The lowest efficiency of conversion of DOC into Cs was found in adrenal homogenates of animals fed sunflower oil diets. This oil is rich in oleic acid and linoleic acid, which were used in studies by Widmaier et al. (1992) and Sarel et al. (1995). Even so, the effect of sunflower oil was less profound as compared to cod liver oil, rapeseed oil and lard. No correlation between SFAs and $11 \beta-O H a s e$ activity was found, however, PUFAs intake and $11 \beta-O H a s e$ activity were negatively correlated $(\mathrm{r}=-0.25 ; \mathrm{P}<0.02)$ : the higher PUFAs intake, the lower $11 \beta$-OHase activity was observed.

In the present study, fat type in the diet had a significant influence on plasma corticosterone concentration. In comparison to other fats, feeding the animals cod liver oil diets increased the concentration of corticosterone in the blood. No correlation, however, was found between intake of particular fatty acids groups and plasma Cs concentration. Interestingly, the effect of fat type on hormone concentration was observed only in animals fed experimental diets for three weeks. The extension of experimental period to six weeks brought about the unification of the parameter. Moreover, plasma Cs concentration was significantly lower in six-week groups than in rats fed for three weeks only. It is opposite to the effect of feeding period on 11ßOHase activity, which was higher after six weeks feeding as compared three weeks feeding. 11 $\beta$-OHase activity was also shown to be dependent on both fat type and fat level in the diet in six-week groups. Blood corticosterone and enzyme activity adrenal cells were found to be negatively correlated $(\mathrm{r}=-0.55 ; \mathrm{P}<0.0001)$.

The above described relationships are extraordinarily interesting since they indicate prolonged adaptive period to diet with respect to adrenal glands and fast but disappearing reaction of peripheral parameter of HPA axis activity, i.e. plasma corticosterone concentration. As well known, blood concentration of different compounds is determined not only by diet but also by many other factors. Thus, hormone concentration cannot be regarded as a basic parameter of its synthesis. Of much higher importance, with this respect, is the activity of enzymes of hormone biosynthesis pathway, as it was confirmed in the present study.

Similarly to glucocorticoids, leptin plays a fundamental role in the regulation of energy balance of an organism. The amount of leptin synthesized and secreted 
into blood is closely determined by adipose tissue content in the body (Blum, 1997; Coleman et al., 1999). As well known, the level of energy deposited in fat tissue depends on quantity and quality of diet consumed. Among dietary factors, fat intake appears of major importance. There is a considerable volume of literature on the role of dietary fat level in the regulation of blood leptin concentration and of adipose tissue ob gene expression in both humans and rodents. The gathered data provide evidence that consumption of high fat diets stimulates the expression of ob gene and increases the plasma leptin concentration. It is a fast adaptive response to increased energy intake, protecting an organism from the development of diet-dependent obesity (Cooling et al., 1998). Leptin is capable of inhibiting appetite (partly through the inhibition of NPY synthesis in the hypothalamus) and of increasing energy expenditure in brown adipose tissue (likely through activation of sympathetic system) (Van Dijk et al., 1997). However, long-term overconsumption of fat energy disturbs this effect (Lin et al., 2000). The underlying mechanism consists likely in the development of central and peripheral leptin resistance. Lin et al. (1998) showed that the injection of leptin into certain brain structures in rats fed high fat diets for a longer period of time (5-6 weeks) results in central and peripheral leptin resistance. Typical effects of leptin (with respect to regulation of food intake, body weight gain and adipose tissue deposition) were not observed in these rats.

We did not find any significant differences in leptin concentration related to feeding diets either with different fat levels or for different periods of time. Since our 10 and $20 \%$ fat diets supplied 21.7 and $38.8 \%$ energy as fat, respectively, they probably did not differ in energy value and fat content enough to cause expected effects. To some extent, this observation can be confirmed by the lack of correlation between fat and energy intake and plasma leptin concentration. In the quoted studies, however, the differences in energy value of diets and in fat level were much higher. In the study by Lin et al. (1998) 10 and 56\% energy was derived from fat and Stricker-Krongrad et al. (1998) used diets supplying 14.1 and 72.5\% energy as fat.

Physiological effects of leptin in target cells are mediated through binding to and activation of its membrane receptor Ob-R. It is a trans-membrane receptor, thus the functions of cell membrane may play a crucial role in its receptor (Nogalska et al., 2001). Intake and composition of dietary fat determine the functions of membranes by providing fatty acids incorporated into membrane phospholipids. Diets rich in PUFAs increase both lateral mobility and rotational diffusion of inner or trans-membrane proteins and lipids, such as leptin receptor (Heshka et al., 2001). Heshka et al. (2001) postulated that composition and intake of dietary fat may play a crucial role in the regulation of leptin activity in target cells. Several investigations have been performed, which examined the effects of dietary fat on plasma leptin in rats. Cha and Jones (1998) fed rats diets containing three types of fat: safflower oil, fish oil or beef tallow. Animals fed the safflower oil diet had the highest leptin 
levels, while those fed beef tallow had the lowest. The researchers concluded that PUFAs had a strong hyperleptinemic effect in rats.

In our study, plasma leptin concentration was significantly dependent on dietary fat type, being higher in animals fed diets based on sunflower oil and rapeseed oil than in rats fed diets containing cod liver oil or lard. Our data confirm the results by Cha and Jones (1998). Chemical analysis of experimental fat revealed that plants oils contain considerable amounts of MUFAs and PUFAs, while cod liver oil and lard are a rich source of unsaturated fatty acids and SFAs. Moreover, a significant positive correlation between PUFAs intake and plasma leptin concentration $(\mathrm{r}=$ $0.47 ; \mathrm{P}<0.0001)$ and a negative correlation between SFAs intake and plasma leptin level $(\mathrm{r}=-0.28 ; \mathrm{P}<0.02)$ were found.

As mentioned above, leptin and glucocorticoids exert opposite effects in an organism. Leptin inhibits adrenal steroidogenesis, while glucocorticoids stimulate expression of ob gene. We did not find any significant correlation between corticosterone and leptin levels, however, we found a negative correlation between $11 \beta$ OHase activity and plasma leptin level $(\mathrm{r}=-0.25 ; \mathrm{P}<0,04)$. This fact clearly justifies the feedback loop between adipose tissue and adrenal gland, in which increasing blood leptin level influences negatively corticosterone synthesis in adrenal cortex.

Summing up, our results clearly confirm beneficial effects of diets which contain lower fat level and are rich in PUFAs on the regulation of energy balance and thus in preventing diet-dependent obesity. Such a diet decreases the activity of key enzyme in the glucocorticoid biosynthesis pathway in adrenal cortex and contributes to the increase in leptin secretion into blood.

\section{REFERENCES}

Arvaniti K., Deshaies Y., Richard D., 1998. Effect of leptin on energy balance does not require the presence of intact adrenals. Amer. J. Physiol. 275, R105-R111

Blum W.F., 1997. Leptin: the voice of the adipose tissue. Hormone Res. 48, Suppl. 4, 2-8

Cha M.C., Jones P.J., 1998. Dietary fat type and energy restriction interactively influence plasma leptin concentration in rats. J. Lipid Res. 39, 1655-1660

Coleman R.A., Herrmann T.S., 1999. Nutritional regulation of leptin in humans. Diabetologia 42, 639-646

Cooling J., Barth J., Blundell J., 1998. The high-fat phenotype: Is leptin involved in the adaptive response to a high-fat (high energy) diet? Int. J. Obes. 22, 1132-1135

De Vos P., Saladin R., Auwerx J., Staels B., 1995. Induction of ob gene expression by corticosteroids is accompanied by body weight loss and reduced food intake. J. Biol. Chem. 270, 15958-15961

Heiman M.L., Ahima R.S., Craft L.S., Schoner B., Stephens T.W., Flier J.S., 1997. Leptin inhibition of the hypothalamic-pituitary-adrenal axis in response to stress. Endocrinology 138, 3859-3863

Heshka J.T., Jones P.J.H., 2001. A role for dietary fat in leptin receptor, OB-Rb, function. Life Sci. 69, 987-1003 
Innis S.M., Rioux F.M., Auestad N., Ackman R.G., 1995. Marine and freshwater fish oil varying in arachidonic, eicosapentaenoic and docosahexaenoic acids differ in their effects on organ lipids and fatty acids in growing rats. J. Nutr. 125, 2286-2293

Kamara K., Eskay R., Castonguay T., 1998. High-fat diets and stress responsivity. Physiol. Behav. $64,1-6$

Korbonits M., Trainer P.J., Little J.A., Edwards R., Kopelman P.G., Besser G.M., Svec F., Grossman A.B., 1997. Leptin levels do not change acutely with food administration on normal or obese subjects, but are negatively correlated with pituitary-adrenal activity. Clin. Endocrinol. 46, $751-757$

Leakey J.E.A., Seng J.E., Barnas C.R., Baker V.M., Hart R.W., 1998. A mechanistic basis for the beneficial effects of caloric restriction on longevity and disease: consequences for the interpretation of rodent toxicity studies. Int. J. Toxicol. 17, Suppl 2, 5-56

Lin S., Storlien L.H., Huang X., 2000. Leptin receptor, NPY, POMC, mRNA expression in the diet - induced obese mouse brain. Brain Res. 875, 89-95

Lin X., Chavez M.R., Bruch R.C., Kilroy G.E., Simmons L.A., Lin L., Braymer D., Bray G.A., York D.A., 1998. The effects of a high fat diet on leptin mRNA, serum leptin and the response to leptin are not altered in a rat strain susceptible to high fat diet - induced obesity. J. Nutr. 128, 1606-1613

Lo M.J., Kau M.M., Chen Y.H., Tsai S.C., Chiao Y.C., Chen J.J., Liaw C., Lu C.C., Lee B.P., Chen S.C., Fang V.S., Ho L.T., Wang P.S., 1998. Acute effects of thyroid hormones on the production of adrenal cAMP and corticosterone in male rats. Amer. J. Physiol. 274, E238-E245

Lowry O.H., Rosebrough N.J., Favy A.L., Randall O.P., 1951. Protein measurement with Follin phenol reagent. J. Biol. Chem. 193, 265-275

Nogalska A., Świerczyński J., 2001. Leptin - a multifunctional hormone. Post. Biochem. 47, 200211

Pralong F.P., Roduit R., Waeber G., Castillo E., Mosimann F., Thorens B., Gaillard R.C., 1998. Leptin inhibits directly glucocorticoid secretion by normal human and rat adrenal gland. Endocrinology $139,4264-4268$

Raatz S.K., Bibus D., Thomas W., Kris-Etherton P., 2001. Total fat intake modifies plasma fatty acids composition in humans. J. Nutr. 131, 231-234

Sarel I., Widmaier E.P., 1995. Stimulation of steroidogenesis in cultured rat adrenocortical cells by unsaturated fatty acids. Amer. J. Physiol. 268, R1484-R1490

Solano J.M., Jacobson L., 1999. Glucocorticoids reverse leptin effects on food intake and body fat in mice without increasing NPY mRNA. Amer. J. Physiol. 277, E708-E716

Strack A.M., Sebastian R.J., Schwartz M.W., Dallman M.F., 1995. Glucocorticoids and insulin: reciprocal signals for energy balance. Amer. J. Physiol. 268, R142-R149

Stricker-Krongrad A., Cumin F., Burlet C., Beck B., 1998. Hypothalamic neuropeptide Y and plasma leptin after long-term high-fat feeding in the rat. Neurosci. Lett. 254, 157-160

Tannenbaum B.M., Brindley D.N., Tannenbaum G.S., Dallman M.F., McArthur M.D., Meaney M.J., 1997. High-fat feeding alters both basal and stress-induced hypothalamic-pituitary-adrenal activity in the rat. Amer. J. Physiol. 273, E1168-E1177

Tataranni P.A., Larson D.E., Snitker S., Young J.B., Flatt J.P., Ravussin E., 1996. Effecs of glucocorticoids on energy metabolism and food intake in humans. Amer. J. Physiol. 271, E317E325

Trocki O., Baer D.J., Castonguay T.W., 1995. Comparison of effects of adrenalectomy and RU-486 in rats given a choice of maintenance diet and fat supplement. Amer. J. Physiol. 269, R708-R719

Vahouny G.V., Hodges V.A., Treadwell C.R., 1979. Essential fatty acids deficiency and adrenal cortical function in vitro. J. Lipid Res. 20, 154-161 
Vallette G., Vanet A., Sumida C., Nunez E.A., 1991. Modulatory effects of unsaturated fatty acids on the binding of glucocorticoids to rat liver glucocorticoid receptors. Endocrinology 129, 1363-1369

Van Dijk G., Donahey J.C.K., Thiele T.E., Scheurink A.J.W., Steffens A.B., Wilkinson C.W., Tenenbaum R., Campfield L.A., Burn P., Seeley R.J., Woods S.C., 1997. Central leptin stimulates corticosterone secretion at the onset of the dark phase. Diabetes 46, 1911-1914

Wabitsch M., Jensen P.B., Blum W.F., Christoffersen C.T., Englaro P., Heinze E., Rascher W., Teller W., Tornqvist H., Hauner H., 1996. Insulin and cortisol promote leptin production in cultured human fat cells. Diabetes 45, 1435-1438

Wang J., Alexander J.T., Zheng P., Yu H.J., Dourmashkin J., Leibowitz S.F., 1998. Behavioral and endocrine traits of obesity-prone and obesity-resistant rats on macronutrient diets. Amer. J. Physiol. 274, E1057-E1066

Widmaier E.P., 1997. Fatty acids regulation of endocrine activity. In: S. Yehuda, D.I. Mostofsky (Editors). Handbook of Essential Fatty Acid: Biology, Biochemistry, Physiology, and Behavioral Neurobiology. Humana Press Inc., Totowa, NJ, pp.115-135

Widmaier E.P., Rosen K., Abbott B., 1992. Free fatty acids activate the hypothalamic-pituitaryadrenocortical axis in rats. Endocrinology 131, 2313-2318

Zakrzewska K.E., Cusin I., Sainsbury A., Rohner-Jeanrenaud F., Jeanrenaud B., 1997. Glucocorticoids as counterregulatory hormones of leptin. Diabetes 46, 717-719

\section{STRESZCZENIE}

Aktywność 11ß-hydroksylazy deoksykortykosteronu w nadnerczach oraz stężenie kortykosteronu i leptyny w osoczu krwi szczurów karmionych dietami zawierającymi różny rodzaj i poziom tluszczu przez 3 lub 6 tygodni

Zbadano wpływ różnego rodzaju tłuszczu (olej słonecznikowy i rzepakowy, tran i smalec) w dietach zawierających podwyższony $(10 \% \mathrm{w} / \mathrm{w})$ i wysoki $(20 \% \mathrm{w} / \mathrm{w})$ poziom tego składnika na aktywność 11ß-hydroksylazy dezoksykortykosteronu w homogenatach nadnerczy oraz stężenie kortykosteronu i leptyny w osoczu krwi szczurów. Aktywność enzymu oznaczono jako procent konwersji DOC do Cs podczas 2-godzinnej inkubacji; stężenie kortykosteronu i leptyny w osoczu oznaczono metodą RIA. 102 samce szczurów rasy Wistar karmiono dietami przez 3 lub 6 tygodni. Wykazano istotny wpływ rodzaju zastosowanego w dietach tłuszczu na badane parametry: aktywność enzymu była najwyższa u zwierząt karmionych dietami zawierającymi tran, najniższa - u zwierząt otrzymujących olej słonecznikowy. Stężenie leptyny w osoczu u zwierząt otrzymujących olej słonecznikowy i rzepakowy było wyższe niż zwierząt otrzymujących tran i smalec. U szczurów karmionych dietami zawierającymi tran stężenie kortykosteronu w osoczu było najwyższe w porównaniu ze zwierzętami karmionymi innymi rodzajami tłuszczu. Ponadto, aktywność 11ß-hydroksylazy była wyższa u szczurów otrzymujących diety wysokotłuszczowe niż u zwierząt otrzymujących diety z mniejszą zawartością tłuszczu. Nie wykazano wpływu poziomu tłuszczu, zawartego w dietach, na oznaczane parametry osocza. Wydłużenie okresu karmienia do 6 tygodni spowodowało wzrost aktywności $11 \beta$-hydroksylazy w porównaniu z 3-tygodniowym okresem doświadczalnym; odwrotny efekt obserwowano w przypadku stężenia kortykosteronu w osoczu. 